\title{
Nicotine inhibits CD24 expression in Lewis lung carcinoma cells by upregulation of RAS expression
}

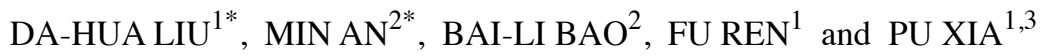 \\ ${ }^{1}$ Biological Anthropology Institute, Liaoning Medical University; ${ }^{2}$ Department of Cardiology, \\ Jinzhou Central Hospital; ${ }^{3}$ Department of Cell Biology, College of Basic Medical Science, \\ Liaoning Medical University, Jinzhou, Liaoning 121000, P.R. China
}

Received December 12, 2017; Accepted May 8, 2018

DOI: $10.3892 /$ ijo.2018.4415

\begin{abstract}
Cluster of ddifferentiation 24 (CD24) is a widely used cancer stem cell (CSC) marker in numerous cancer types. However, a number of studies have shown that CD24 is a prognostic marker, but not a CSC marker for lung adenocarcinoma. In the present study, firstly, bioinformatic analyses were used to identify the CD24 mRNA levels in the subtypes of lung cancer. Secondly, CD $24^{\text {high }}$ and CD2 $4^{\text {low }}$ cells were isolated from the side population of Lewis lung carcinoma (LLC) cells using flow cytometry. Furthermore, the stemness of $\mathrm{CD} 24^{\text {high }}$ and $\mathrm{CD} 24^{\text {low }}$ cells were determined in vivo and in vitro. Lastly, the mechanism(s) of nicotine-inhibited CD24 expression in LLC cells were assessed. The main findings of this study are that: i) CD24 could be used as a prognostic marker for human lung adenocarcinoma; ii) the in vitro and in vivo experiments did not determine a significant influence of CD24 on the tumorgenicity of LLC cells; and iii) nicotine inhibited CD24 expression in LLC cells by upregulation of RAS. However, the detailed mechanism(s) of these results require further analysis.
\end{abstract}

\section{Introduction}

Lung cancer is a major cause of cancer-related mortality in China $(1,2)$. The overall 5-year survival rate for patients with

Correspondence to: $\mathrm{Dr} \mathrm{Pu} \mathrm{Xia}$, Department of Cell Biology, College of Basic Medical Science, Liaoning Medical University, 40, Section 3, Songpo Road, Linghe, Jinzhou, Liaoning 121000, P.R. China

E-mail: nn001007@163.com

Dr Fu Ren, Biological Anthropology Institute, Liaoning Medical University, 40, Section 3, Songpo Road, Linghe, Jinzhou, Liaoning 121000, P.R. China

E-mail:rf@jzmu.edu.cn

*Contributed equally

Key words: cluster of ddifferentiation 24, lung cancer, cancer stem cell, nicotine, prognosis non-small cell lung cancer (NSCLC) is $\sim 17.1 \%$ (2). In the past years, extensive research has been performed to obtain a better understanding of the underlying molecular biology of lung cancer (3-5). Recent studies have shed light on the role of cancer stem cells (CSCs) in lung cancer (6-8).

CSCs are a subpopulation of cells within a tumor that possess self-renewal and tumor-initiating capacities (9). Cluster of ddifferentiation 24 (CD24) is a small membrane glycoprotein that has emerged as a major determinant of stemness in various cancer types $(10,11)$. Although CD24 has been used extensively in combination with other putative markers to isolate CSCs (12-14), the lack of their universal expression limits their usage to lung cancer $(15,16)$. However, CD24 has been suggested as a biomarker for carcinoma progression in lung cancer $(17,18)$.

The aim of the present study was to assess the tumor promotion roles of CD24 in the subtypes of lung cancer. Firstly, the significance of CD24 mRNA in human lung cancer was evaluated using the Oncomine database. Secondly, CD2 $4^{\text {high }}$ and CD $24^{\text {low }}$ cells were isolated from Lewis lung carcinoma (LLC) cells and the tumorigenic ability of these cells in vitro and in vivo was identified. Furthermore, a focus was placed on the roles of nicotine in CD24 expression, and the associated molecular signaling pathways were investigated. The findings of this study may be useful in improving the clinical effectiveness for a better prognosis in patients with lung adenocarcinoma.

\section{Materials and methods}

Oncomine database analysis. CD24 mRNA levels in NSCLC tissues were compared with their matched normal tissues using the Oncomine database (http://www.oncomine.org). The threshold used to obtain the most significant probes of the queried gene for each microarray data included a 2-fold difference in expression between cancer and normal tissues, with a $\mathrm{P}$-value of $<1 \times 10^{-4}$.

Kaplan-Meier plotter analysis. The prognostic value of CD24 mRNA in lung cancer was analyzed using Kaplan-Meier (KM)-Plotter (http://kmplot.com/analysis/). Overall survival of the patients with high and low levels of $C D 24$ mRNA was shown by the log-rank test. 
Cell culture. LLC cells were obtained from the American Type Culture Collection (Manassas, VA, USA) and grown in RPMI-1640 medium (Hyclone, Logan, UT, USA) supplemented with $10 \%$ fetal bovine serum and antibiotics $(100 \mathrm{U} / \mathrm{ml}$ penicillin and $100 \mu \mathrm{g} / \mathrm{ml}$ streptomycin). Cells were maintained in a humidified cell incubator with $5 \% \mathrm{CO}_{2}$ at $37^{\circ} \mathrm{C}$.

Fluorescence-activated cell sorting (FACS). Sorting of the side population (SP) cells from LLC cells was performed as described previously (19). SP cells were washed twice with PBS and suspended in $100 \mu \mathrm{l}$ assay buffer [PBS, $0.5 \%$ bovine serum albumin (BSA), 2 mM EDTA (pH 7.2)] with $10 \mu 1$ phycoerythrin (PE)-conjugated anti-CD24 antibody (1:50; catalog no. 555428; BD Biosciences, Franklin Lakes, NJ, USA) and $20 \mu \mathrm{l}$ fluorescein isothiocyanate-conjugated anti-CD133/2 (clone 293C3) antibody [1:20; catalog no. 130-104-322; Miltenyi Biotec Technology and Trading (Shanghai) Co., Ltd. Shanghai, China]. The cells were then incubated in the dark at $4^{\circ} \mathrm{C}$ for $30 \mathrm{~min}$, washed twice with $1 \mathrm{ml}$ assay buffer and centrifuged at $300 \mathrm{xg}$ for $10 \mathrm{~min}$. The cell pellet was subjected to FACS using a BD Aria II sorter (BD Biosciences).

Reverse transcription-polymerase chain reaction (PCR). Total RNA was isolated from cells using an RNeasy Mini kit (Beijing Bomed Gene Technology Co., Ltd., Beijing, China). cDNA was reverse transcribed from $1 \mu \mathrm{g}$ total RNA using a Takara Reverse Transcription kit (Takara Biotechnology, Co., Ltd., Dalian, China), and then amplified using the following primers: $C D 24$ sense, 5'-ACTCAGGCCAGGAAAC GTCTCT-3' and antisense, 5'-AACAGCCAATTCGAGGTG GAC-3'; ATP-binding cassette subfamily G member 2 (Junior blood group) (ABCG2) sense, 5'-AGCTGCAAGGAAAGATC CAA-3' and antisense 5'-TCCAGACACACCACGGATAA-3'; and GAPDH sense, 5'-AGAAGGCTGGGGCTCATTTG-3' and antisense, 5'-AGGGGCCATCCACAGTCTTC-3'. The PCR products were electrophoresed on a $1.5 \%$ agarose gel, and visualized by ethidium bromide staining under an ultraviolet imaging system (UVP, LLC, Phoenix, AZ, USA). The RT-PCR conditions were as follows: $10 \mathrm{~min}$ at $95^{\circ} \mathrm{C}$ for denaturation, followed by 35 cycles of $20 \mathrm{sec}$ at $95^{\circ} \mathrm{C}, 40 \mathrm{sec}$ at $56^{\circ} \mathrm{C}$ and $30 \mathrm{sec}$ at $72^{\circ} \mathrm{C}$, and a final extension step of $5 \mathrm{~min}$ at $72^{\circ} \mathrm{C}$.

Immunofluorescence. Cells were fixed with $4 \%$ paraformaldehyde for $30 \mathrm{~min}$, followed by washing twice in PBS at room temperature (RT) for $5 \mathrm{~min}$. Non-specific binding sites were blocked with 3\% BSA in PBS for $1 \mathrm{~h}$ at RT. PE-conjugated anti-CD24 antibody (as aforementioned), diluted in 3\% BSA/ PBS, was applied overnight at $4^{\circ} \mathrm{C}$. For every coverslip, the cells were observed and images were captured in 5 random fields using an Olympus CX71 fluorescence microscope (Olympus Corporation, Tokyo, Japan).

Colony-formation assay. Cells were plated at a density of $2 \times 10^{5}$ cells/well in 24 -well plates under serum-free, colonyspecific conditions. Fresh aliquots of epidermal growth factor and basic fibroblast growth factor were added every day. Subsequent to culturing the cells for 3 weeks, colonies were visible under a light microscope (Olympus CX31; Olympus).
Transwell assay. Cell suspension (200 $\mu \mathrm{l} ; 1 \times 10^{5}$ cells $/ \mathrm{ml}$, RPMI-1640 medium with $1 \%$ FBS) was placed into the upper chamber of a Transwell $(8-\mu \mathrm{M}$ pore size polycarbonate membrane; Cell Biolabs, San Diego, CA, USA). In the lower chamber, RPMI-1640 medium with 10\% FBS was added. Subsequent to culture for $24 \mathrm{~h}$, the cells that had migrated through and adhered to the lower surface of the membrane were fixed with paraformaldehyde for $15 \mathrm{~min}$ and stained with $0.1 \%$ crystal violet for $10 \mathrm{~min}$ at RT. Next, five fields of view were randomly selected for the counting of cells under a light microscope (Olympus CX31; Olympus).

Nicotine treatment and Ras inhibitor (salirasib). According to the method used in the study by Chu et al (20), CD24 ${ }^{\text {low }}$ and CD24 ${ }^{\text {high }}$ cells were split every 3 days with medium supplemented with $0.5 \mu \mathrm{M}$ nicotine to keep the drug at a constant concentration. For the controls, CD2 $4^{\text {low }}$ and CD24 $4^{\text {high }}$ cells treated with nicotine were incubated with salirasib $(100 \mu \mathrm{M}$; 162520-00-5; Tocris Bioscience, Bristol, UK) for $24 \mathrm{~h}$ at $37^{\circ} \mathrm{C}$.

In vivo assays. Liaoning Medical University Ethics Committee (Jinzhou, Liaoning, China) approved the research protocols performed in this study. NOD SCID mice (25-40 g; 4 to 6-weeks-old; male; NOD.CB17-Prkdescid/NcrCrl; Charles River Laboratories, Inc., Wilmington, MA, USA) received standard laboratory food and water ad libitum and were maintained in micro-isolator cages with filtered air and handled under sterile conditions under a laminar flow hood. A subcutaneous injection of cells $\left[1 \times 10^{7}\right.$ cells in $200 \mu \mathrm{l}$ PBS, including main population (MP), SP, CD24 ${ }^{\text {high }}$, $\mathrm{CD} 24^{\text {low }}, \mathrm{CD} 133^{\text {high }} \mathrm{CD} 24^{\text {high }}$ or $\mathrm{CD} 133^{\text {high }} \mathrm{CD} 24^{\text {low }} ; 30$ mice in each treatment group] was administered into the flank of each mouse. Tumors were measured using calipers, and tumor volumes were calculated (tumor volume $=$ length $\mathrm{x}$ width $^{2} \mathrm{x}$ 0.52) (21). Once the tumor diameters had reached 3-5 $\mathrm{mm}$, the mice were used in the following studies. According to the methods used in the study by Cavarra et al (22), male mice injected with $\mathrm{CD} 24^{\text {high }}$ or $\mathrm{CD} 24^{\text {low }}$ cells were exposed to the smoke of four cigarettes/day at 10 a.m. and 4 p.m. for 3 months (1.2 mg of nicotine; Honghe filter cigarettes; Honghe Cigarette Factory, Yunnan, China), 1 month prior to cell inoculation and 2 months after cell inoculation), in specially designed cages. The mice were examined at 0 , $10,20,30,40,50$ and 60 days, and tumor growth was evaluated by measuring the length and width of the tumor mass. Subsequently, the animals were euthanized with pentobarbital sodium via the tail vein $(100 \mathrm{mg} / \mathrm{kg})$. The survival state of the immunodeficient mice was observed day and night, and euthanasia was available to use at the first sign of any mental or dietary problems.

Immunohistochemical staining. Endogenous peroxidase activity was blocked in 4- $\mu$ m tumor sections with $3 \%$ hydrogen peroxide for $30 \mathrm{~min}$ at RT. Antigen retrieval was performed in citrate buffer (10 mM; pH 6.0) for $30 \mathrm{~min}$ at $95^{\circ} \mathrm{C}$ in a pressure cooker. Primary antibodies were incubated with sections at 1:500 overnight at $4^{\circ} \mathrm{C}$ (Table I). Sections were then incubated with horseradish peroxidase-labeled polymer-conjugated goat anti-mouse/goat anti-rabbit secondary antibody (1:100; catalog 

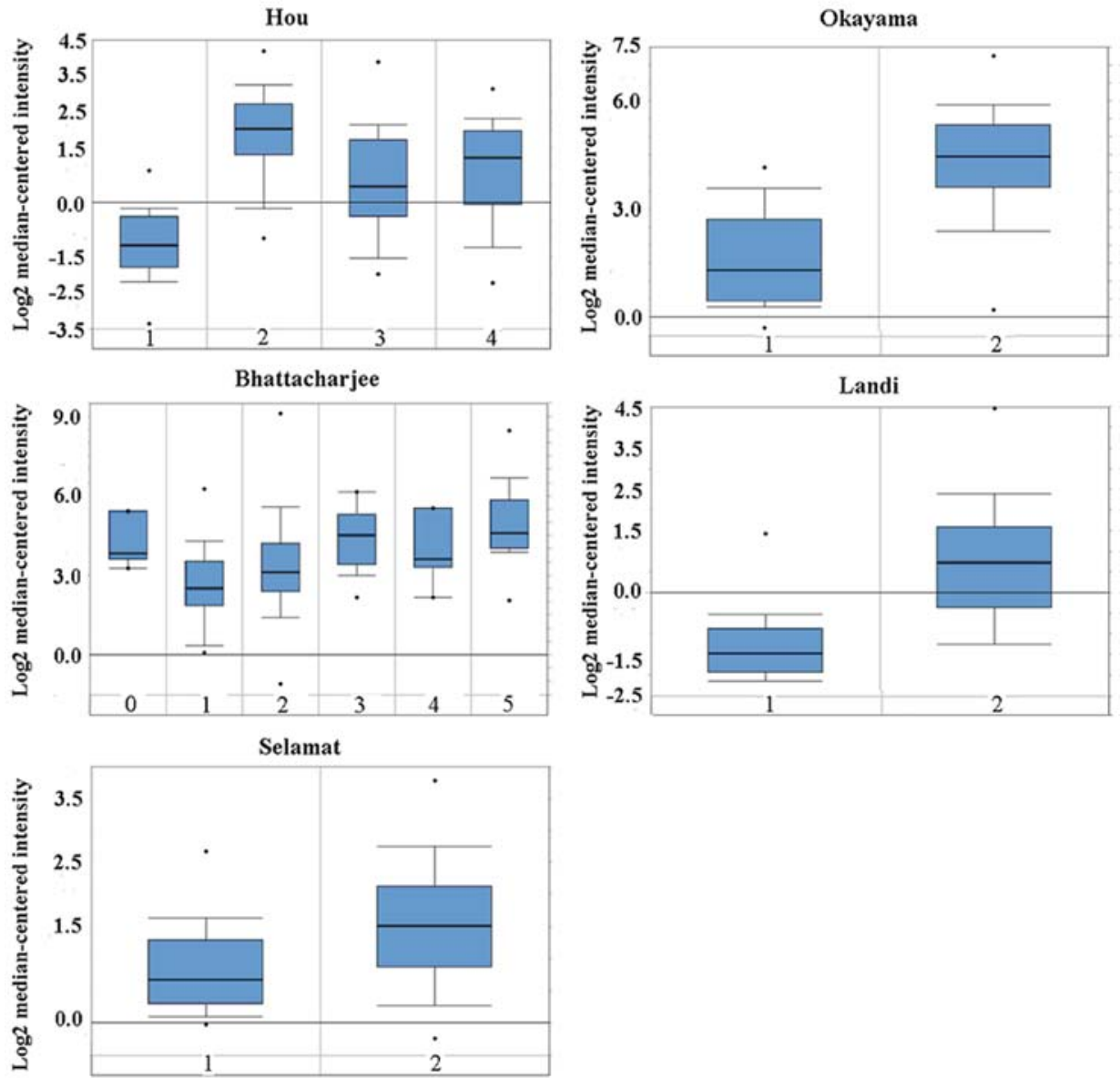

Figure 1. Cluster of ddifferentiation 24 mRNA was evaluated in subtypes of lung cancer using Oncomine analysis. Hou: 1, lung ( $\mathrm{n}=65$ ); 2 , large cell lung carcinoma ( $\mathrm{n}=19)$; 3, lung adenocarcinoma $(\mathrm{n}=45)$; and 4 , squamous cell lung carcinoma $(\mathrm{n}=27)$. Bhattacharjee: 0 , no value $(\mathrm{n}=7) ; 1$, lung $(\mathrm{n}=17)$; 2 , lung adenocarcinoma $(\mathrm{n}=132) ; 3$, lung carcinoid tumor $(\mathrm{n}=20) ; 4$, small cell lung carcinoma $(\mathrm{n}=6)$; and 5 , squamous cell lung carcinoma $(\mathrm{n}=21)$. Okayama: 0 , lung $(\mathrm{n}=20)$; and 1, lung adenocarcinoma $(\mathrm{n}=226)$. Selamat: 1 , lung $(\mathrm{n}=58)$; and 2, lung adenocarcinoma $(\mathrm{n}=58)$. Landi: 1, lung $(\mathrm{n}=49)$; and 2 , lung adenocarcinoma $(\mathrm{n}=58)$. The data are presented as the mean \pm standard deviation. The dots represent abnormal values/outliers.

no. A0208/A0216; Beyotime Institute of Biotechnology, Beijing, China) for $60 \mathrm{~min}$ at RT, followed by incubation with a streptavidin horseradish peroxidase complex (Beyotime Institute of Biotechnology) for $60 \mathrm{~min}$ at RT. Bound antibody was visualized with 3,3'-diaminobenzidine tetrahydrochloride (Beyotime Institute of Biotechnology). Sections were also counterstained with hematoxylin for $30 \mathrm{sec}$ at RT (Beyotime Institute of Biotechnology). The results were visible under a light microscope (Olympus CX31; Olympus).

Western blot analysis. Protein was extracted in lysis buffer (P0013B; Beyotime Institute of Biotechnology) for $30 \mathrm{~min}$ on ice. The extract was centrifuged at $4,000 \times \mathrm{g}$ for $5 \mathrm{~min}$ at $4^{\circ} \mathrm{C}$ to remove debris. Total protein concentration was determined using the bicinchoninic acid protein assay kit (P0010; Beyotime Institute of Biotechnology). Extracted proteins (30 $\mu \mathrm{g})$ were separated by $10 \%$ SDS-polyacrylamide gel electrophoresis and transferred to nitrocellulose membranes. Membranes were blocked in 5\% BSA/Tris-buffered saline plus Tween-20 at RT for $1 \mathrm{~h}$ and then incubated with primary antibodies at $4^{\circ} \mathrm{C}$ overnight (Table $\mathrm{I}$ ). The reaction was followed by probing with peroxidase-coupled secondary antibodies at 1:1,000 dilution (catalog no. A0216; goat antimouse; and catalog no. A0208; goat anti-rabbit; Beyotime
Institute of Biotechnology), and binding results were visualized by enhanced chemiluminescence kit (Amersham; GE Healthcare, Chicago, IL, USA).

Ingenuity Pathway Analysis. The Ingenuity Pathway Analysis software (Ingenuity ${ }^{\circledR}$ Systems; www.ingenuity.com) was used to build networks and identify pathways of CD24 based on data mining.

Statistical analysis. Each experiment was performed in triplicate. Data were analyzed using GraphPad Prism 5 software (GraphPad Software, San Diego, CA, USA). Statistical analysis was performed using one-way analysis of variance and Tukey's post hoc test. $\mathrm{P}<0.05$ was considered to indicate a statistically significant difference.

\section{Results}

Associations between CD24 status and clinical parameters of lung cancer patients. Oncomine analysis of cancer versus normal tissue showed that the CD24 mRNA level was higher in lung adenocarcinoma, large cell lung carcinoma, squamous cell lung carcinoma and small cell lung carcinoma (Fig. 1). No difference in CD24 mRNA was found between male and female 
Table I. Antibodies used in the western blotting and immunohistochemistry analyses.

\begin{tabular}{|c|c|c|c|}
\hline Protein & Producer & Catalog no. & Dilution \\
\hline HSP90 & $\begin{array}{l}\text { Cell Signaling } \\
\text { Technology, Inc. }\end{array}$ & 4874 & $1: 100$ \\
\hline CD24 & $\begin{array}{l}\text { Santa Cruz } \\
\text { Biotechnology, Inc. }\end{array}$ & sc-7034 & $1: 200$ \\
\hline p-RAF & $\begin{array}{l}\text { Santa Cruz } \\
\text { Biotechnology, Inc. }^{\text {b }}\end{array}$ & sc-16806 & $1: 200$ \\
\hline p-RAS & $\begin{array}{l}\text { Santa Cruz } \\
\text { Biotechnology, Inc. }^{\text {b }}\end{array}$ & sc- 521 & $1: 200$ \\
\hline E-cadherin & $\begin{array}{l}\text { Santa Cruz sc-8426 } \\
\text { Biotechnology, Inc. }\end{array}$ & 1:100 & \\
\hline$\beta$-actin & $\begin{array}{l}\text { Santa Cruz } \\
\text { Biotechnology, Inc. }\end{array}$ & sc-47778 & $1: 1,000$ \\
\hline
\end{tabular}

aDanvers, MA, USA; ' Dallas, TX, USA. HSP90, heat shock protein 90; CD24, cluster of ddifferentiation 24; p-, phosphorylated.
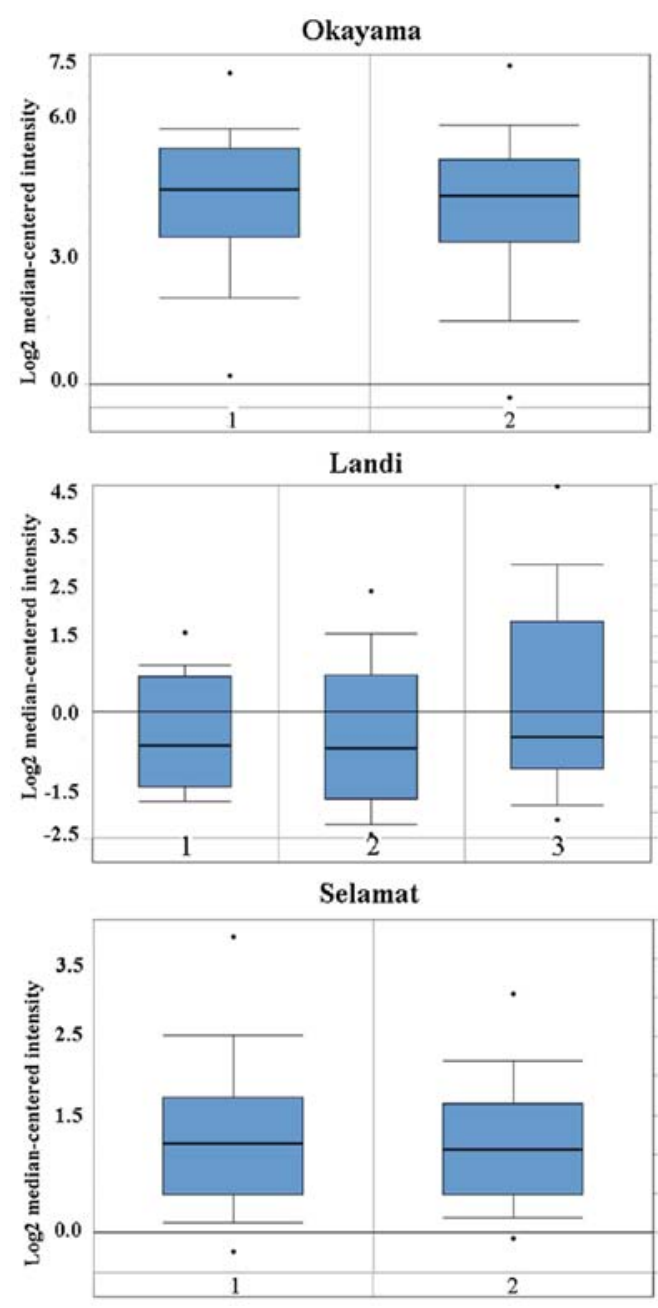

Figure 2. Cluster of ddifferentiation 24 mRNA was evaluated in lung cancer patients with different smoking statuses. Okayama: 1 , never smoker $(\mathrm{n}=123)$; and 2. Smoker $(n=123)$. Selamat: 1 , never smoker $(n=59)$; and 2 , smoker $(\mathrm{n}=57)$. Landi: 1 , never smoker $(\mathrm{n}=31) ; 2$, former smoker $(\mathrm{n}=36)$; and 3 , current smoker $(\mathrm{n}=40)$.
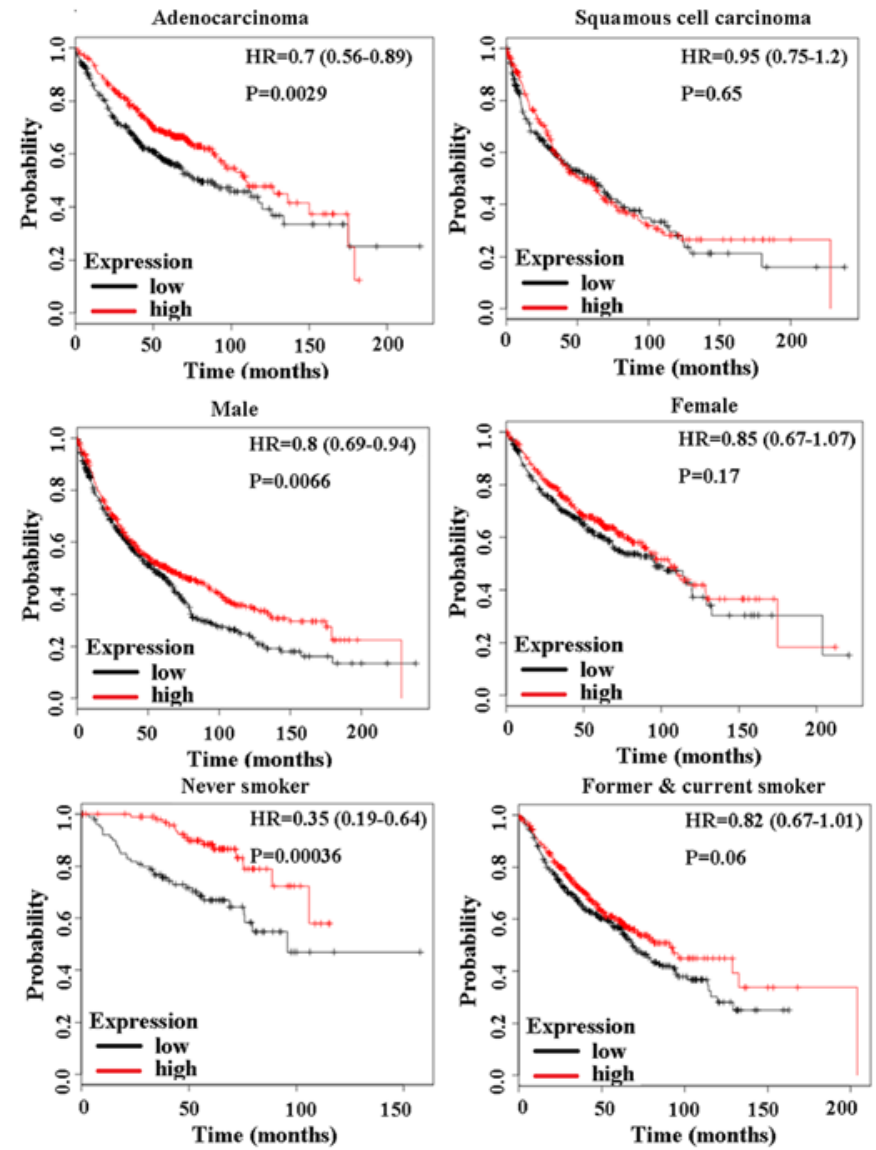

Figure 3. Kaplan-Meier survival analysis of cluster of ddifferentiation 24 mRNA in subtypes of lung cancer was performed using datasets compiled at Kaplan Meier-plotter. HR, hazard ratio.

lung cancer patients (data not shown). Notably, the patients aged 40 to 49 years old exhibited a higher CD24 mRNA level compared with that of patients of other age groups (data not shown). Another notable result was that smoking decreased CD24 expression in lung cancer patients (Fig. 2).

In addition, the prognostic values of CD24 mRNA were analyzed in subtypes of lung cancer by KM-plotter. CD24 mRNA can be used as a prognostic marker for patients with lung adenocarcinoma ( $\mathrm{P}=0.0029)$ (Fig. 3). No influence of $C D 24$ mRNA on squamous cell lung carcinoma was found ( $\mathrm{P}=0.65$ ) (Fig. 3). A high level of $C D 24$ mRNA was shown to improve the survival rate of male lung cancer patients ( $\mathrm{P}=0.0066)$ (Fig. 3). A high level of $C D 24$ mRNA could also improve the prognosis of never smokers $(\mathrm{P}=0.00036)$, while no influence of $C D 24$ mRNA on former smokers and current smokers was found $(\mathrm{P}=0.06)$ (Fig. 3).

$C D 133^{\text {high }} \mathrm{CD} 24^{\text {low }}$ and $\mathrm{CD} 133^{\text {high }} \mathrm{CD} 24^{\text {high }}$ fractions in $\mathrm{LLC}$ cells. In our previous study, SP cells were isolated from LLC cells using Hoechst 33342 efflux analysis (19). ABCG2 protein is a surface marker of SP cells (19). In the present study, SP cells were further isolated by use of two CSC-specific markers, CD133 and CD24 (Fig. 4A). In addition, it was found that CD24 mRNA and protein expression was significantly higher in the $\mathrm{CD} 133^{\text {high }} \mathrm{CD} 24^{\text {high }}$ cells compared with that in the $\mathrm{CD} 133^{\text {high }} \mathrm{CD} 24^{\text {low }}$ cells (Fig. $4 \mathrm{~B}$ and C). $\mathrm{ABCG} 2$ mRNA and protein was higher in $\mathrm{CD} 133^{\text {high }} \mathrm{CD} 24^{\text {high }}$ 

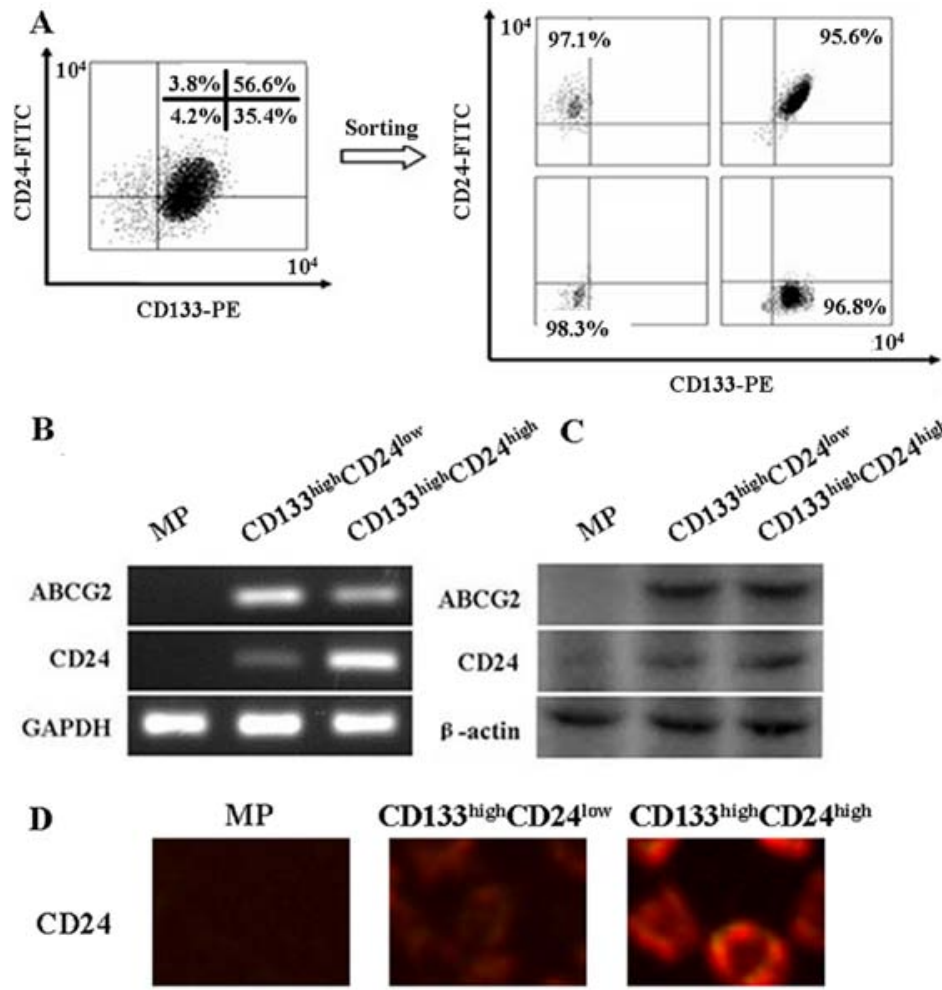

Figure 4. Identification of CD2 $4^{\text {high }}$ and CD2 $4^{\text {low }}$ cells in LLC cell lines. (A) Analysis and sorting of CD24 $4^{\text {high }}$ and CD24 $4^{\text {low }}$ cells was performed on a FACS Vantage SE. (B) The mRNA levels of ABCG2 and CD24 were determined by reverse-transcription-polymerase chain reaction. (C) Expression of ABCG2 and CD24 proteins was determined by western blotting. (D) The expression and location of CD24 protein was stained with PE-conjugated anti-CD24 antibody and examined by immunofluorescence (magnification, x200). CD24, cluster of differentiation 24; LLC, Lewis lung carcinoma; ABCG2, ATP-binding cassette subfamily G member 2 (Junior blood group); PE, phycoerythrin; FITC, fluorescein isothiocyanate; MP, main population.

cells and $\mathrm{CD} 133^{\text {high }} \mathrm{CD} 24^{\text {low }}$ cells than that in MP cells. Immunofluorescence results showed that $\mathrm{CD} 24$ was localized in the membrane of $\mathrm{CD} 133^{\text {high }} \mathrm{CD} 24^{\text {high }}$ and $\mathrm{CD} 133^{\text {high }} \mathrm{CD} 24^{\text {low }}$ cells (Fig. 4D).

Tumorigenic ability of $C D 133^{\text {high }} \mathrm{CD} 24^{\text {low }}$ and $C D 133^{\text {high }} \mathrm{CD} 24^{\text {high }} \mathrm{LLC}$ cells in vitro and in vivo. Colony formation assays were performed to detect the proliferation of MP, SP, CD133 ${ }^{\text {high }} \mathrm{CD} 24^{\text {high }}$ and $\mathrm{CD} 133^{\text {high }} \mathrm{CD} 24^{\text {low }}$ cells. Sphere clusters were clearly observed in SP, CD133 ${ }^{\text {high }} \mathrm{CD} 24^{\text {high }}$ and $\mathrm{CD} 133^{\text {high }} \mathrm{CD} 24^{\text {low }}$ cells $(\mathrm{P}<0.05)$, with no difference among these three cell types (Fig. 5A). Migration of MP, $\mathrm{SP}, \mathrm{CD} 133^{\text {high }} \mathrm{CD} 24^{\text {high }}$ and $\mathrm{CD} 133^{\text {high }} \mathrm{CD} 24^{\text {low }}$ cells was detected using Transwell assay. It was found that more SP, $\mathrm{CD} 133^{\text {high }} \mathrm{CD} 24^{\text {high }}$ and $\mathrm{CD} 133^{\text {high }} \mathrm{CD} 24^{\text {low }}$ cells migrated to the lower membrane compared with MP cells $(\mathrm{P}<0.05)$ (Fig. 5B). No difference in mobility was found among SP, CD $133^{\text {high }} \mathrm{CD} 24^{\text {high }}$ and $\mathrm{CD} 133^{\text {high }} \mathrm{CD} 24^{\text {low }}$ cells (Fig. 5B). Furthermore, it was found that SP, CD133 ${ }^{\text {high }} \mathrm{CD} 24^{\text {high }}$ and $\mathrm{CD} 133^{\text {high }} \mathrm{CD} 24^{\text {low }}$ cells had similar abilities to transfer the tumors into immunocompromised mice (Fig. 6A and B). The diameters of the largest single subcutaneous tumors observed in the SP, CD133 $3^{\text {high }} \mathrm{CD} 24^{\text {high }}$ and $\mathrm{CD} 133^{\text {high }} \mathrm{CD} 24^{\text {low }}$ groups were $4.4 \pm 0.3,4.6 \pm 0.3$ and $4.7 \pm 0.2 \mathrm{~mm}$. These results indicated that CD24 expression did not increase the tumor-forming ability of the LLC cells.

Potential mechanism of nicotine-inhibited CD24 expression. Based on the results of Ingenuity Pathways Analysis
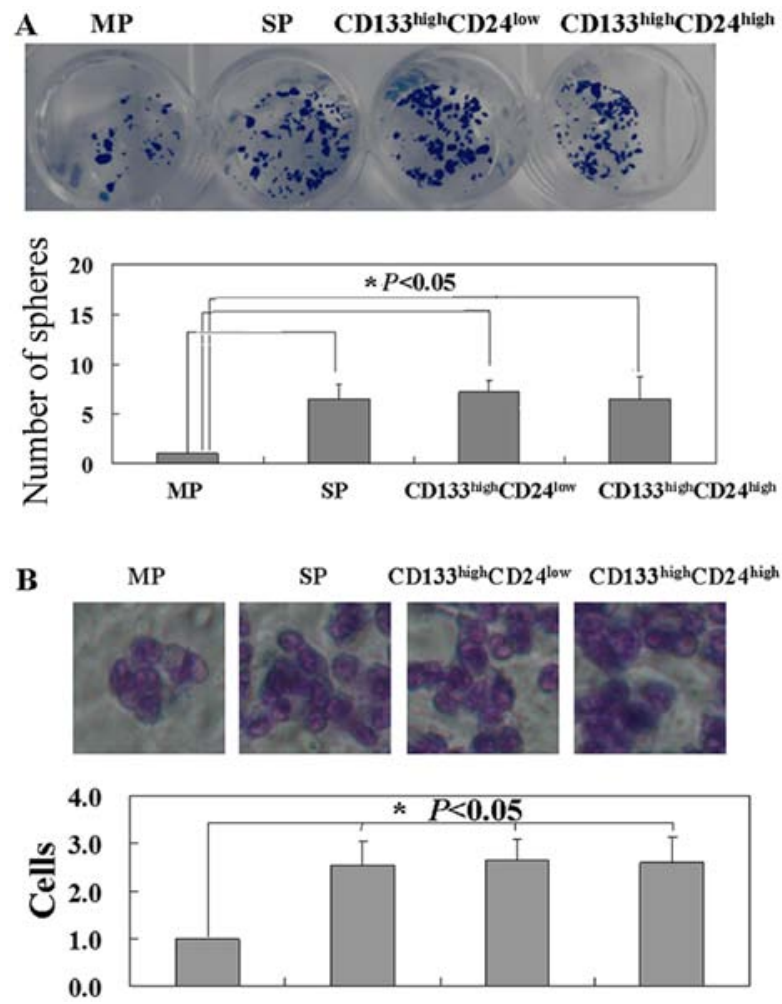

Figure 5. Tumorigenic properties of $\mathrm{CD} 24^{\text {high }}$ and $\mathrm{CD} 24^{\text {low }}$ cells in vitro. (A) The proliferation ratio of MP, SP, CD133 ${ }^{\text {high }} \mathrm{CD} 24^{\text {high }}$ or $\mathrm{CD} 133^{\text {high }} \mathrm{CD} 24^{\text {low }}$ was determined by colony formation assay. (B) The migration of each cell line stained with $0.1 \%$ crystal violet was determined by Transwell assay (magnification, x200). CD24, cluster of differentiation 24; SP, side population; MP, main population. 


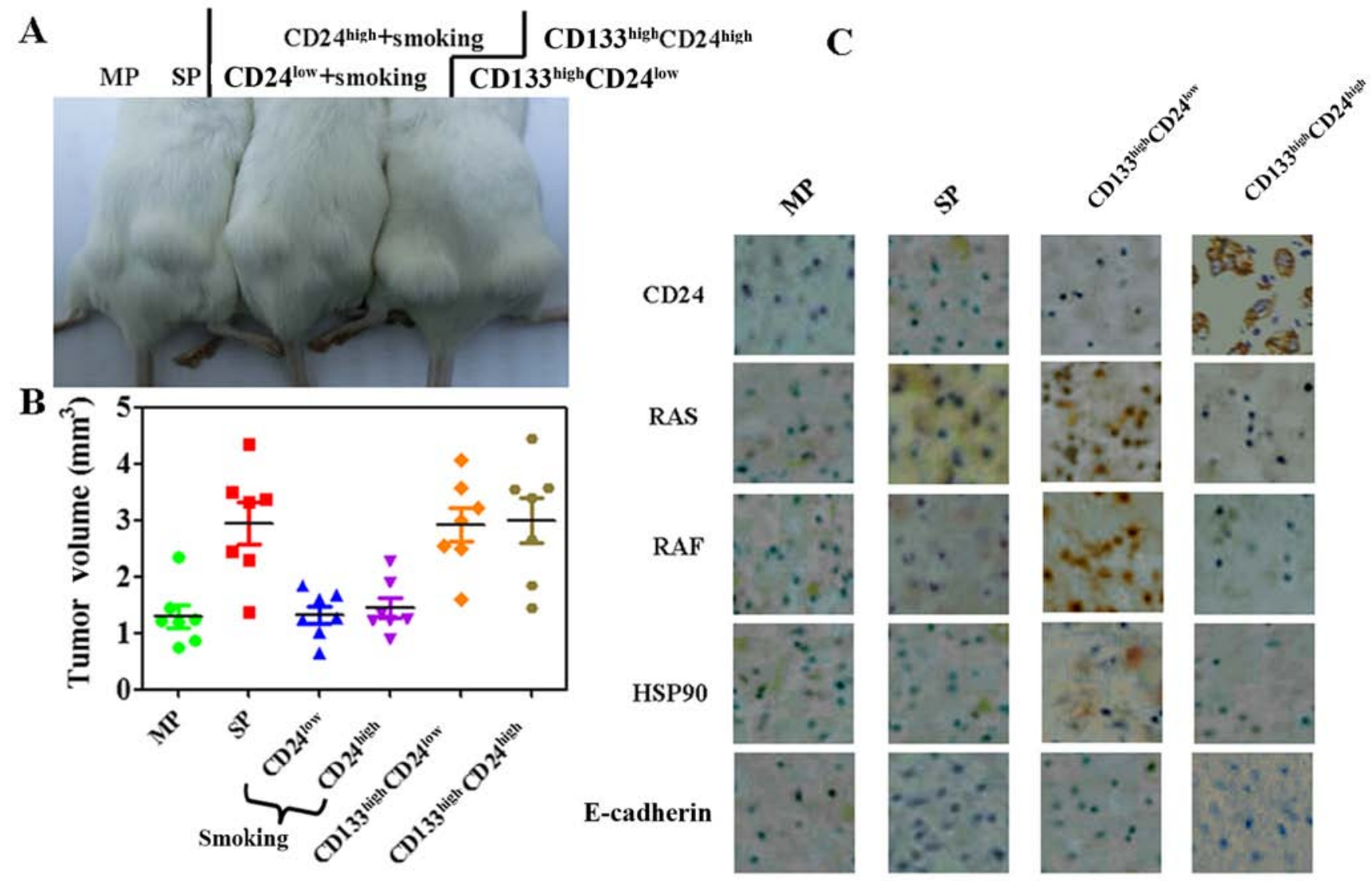

Figure 6. Tumorigenic properties of $\mathrm{CD} 24^{\text {high }}$ and $\mathrm{CD} 24^{\text {low }}$ cells in vivo. (A) Macroscopic appearance of subcutaneous tumors in each group described in the Materials and methods section. (B) Tumor volume of each group described in the Materials and methods section. (C) Immunohistochemical staining of resected tumor tissues from each group using CD24, RAS, RAF, HSP90 and E-cadherin antibodies (magnification, x200). Bound antibody is detected with DAB and appears brown. CD24, cluster of differentiation; HSP90, heat shock protein 90.

A

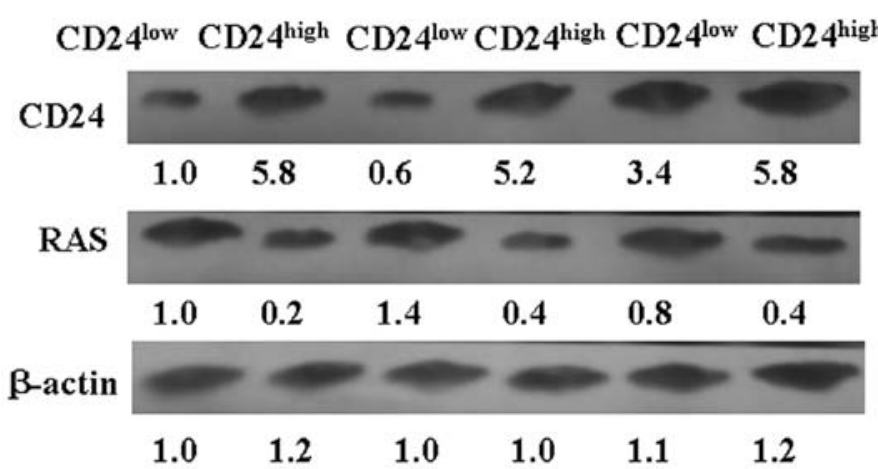

B

Smoking

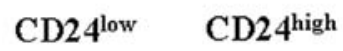

$\mathrm{CD} 24$
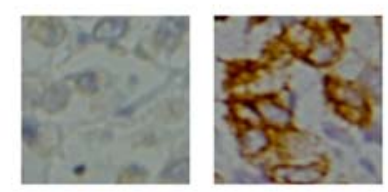

RAS
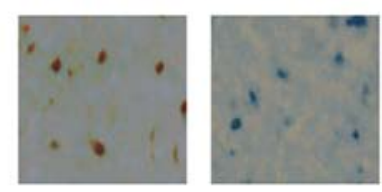

Figure 7. Effects of nicotine on CD24 expression in LLC cells. (A) RAS and CD24 expression in LLC cells following treatment with nicotine was detected using western blotting. (B) The effects of smoking on established xenograft tumor models, as determined using immunohistochemistry (magnification, x200). CD24, cluster of differentiation; LLC, Lewis lung carcinoma.

software (version 6.3; Ingenuity Systems, Redwood, CA, USA), the differentially expressed proteins in CD24expressing cells were determined (data not shown). In addition, immunohistochemistry (IHC) results showed that the level of RAS was markedly higher in the cancer tissues of CD133 ${ }^{\text {high }} \mathrm{CD} 24^{\text {low }}$-injected mice compared with that in the MP group, while almost no RAS expression was found in the CD133 ${ }^{\text {high }} \mathrm{CD} 24^{\text {high }}$ group (Fig. 6C). The results also revealed that CD24 expression was associated with HSP90 expres- sion (Fig. 6C). Low E-cadherin expression was found in all MP, SP, CD133 ${ }^{\text {high }} \mathrm{CD} 24^{\text {high }}$ and CD133 ${ }^{\text {high }} \mathrm{CD} 24^{\text {low }}$ groups (Fig. 6C).

Furthermore, it was found that nicotine treatment inhibited CD24 expression in vitro (Fig. 7A). The level of RAS was moderately increased in CD2 $4^{\text {low }}$ and CD2 $4^{\text {high }}$ LLC cells after nicotine treatment (Fig. 7A). To test the hypothesis that CD24 expression partly depended on downregulation of RAS in LLC cells, salirasib was used as a RAS blocker. Downregulation of 
RAS using salirasib could induce CD24 expression in CD24 ${ }^{\text {low }}$ LLC cells (Fig. 7A). Altogether, these results suggest that nicotine could inhibit CD24 expression in LLC cells via activating RAS.

CD24 $4^{\text {high }}$ and $\mathrm{CD} 24^{\text {low }}$ cell-injected mice were subjected to cigarette smoke, as aforementioned. The tumor volumes of these two groups exhibited no significant changes from the beginning to the end of the experiment (Fig. 6B). IHC results also showed that RAS and CD24 expression were not changed in the mice subjected to smoke (Fig. 7B).

\section{Discussion}

In the present study, the prognostic value of $C D 24$ mRNA in NSCLC was analyzed using the Oncomine database. A number of previous studies have discussed the roles of CD24 in lung cancer $(17,23)$. In the study by Karimi-Busheri et al (17), upregulation of CD24 was observed in $>75 \%$ of NSCLC patients. Kristiansen et al (23) reported a higher incidence of CD24 expression in NSCLC tissues. Consistent with these previous results, the present study also found higher $C D 24$ mRNA expression in lung cancer tissues compared with that in matched normal tissues. Kristiansen et al (23) found that CD24 expression is an independent predictor of a shortened survival time in NSCLC patients. Lee et al (24) demonstrated a significant association between CD24 expression and shorter NSCLC patient survival times. However, in the present study, it was found that $C D 24$ mRNA was associated with a longer survival time in the patients with lung adenocarcinoma. The main reason for this difference may be that dynamic changes of CD24 protein throughout the development of cancer (25). CD24 is a heavily glycosylated protein that also demonstrates increased additional structural flexibility in its mature form (25).

Previous studies showed that CD24 could not be used as a CSC marker for human lung adenocarcinoma $(16,26)$. Roudi et al (16) found that CD24 could not be considered a potential marker for isolating CSCs in the human lung adenocarcinoma A549 cell line. Xu et al (15) also found that CD24- A549 cells possess partial CSC properties, but actually are not CSCs. In the present study, another lung adenocarcinoma cell line, LLC, was used to analyze the roles of CD24 in the stemness of lung adenocarcinoma. The in vitro and in vivo experiments demonstrated that CD $24^{\text {high }}$ LLC cells showed no significant differences in terms of metastasis and tumorgenicity compared with $\mathrm{CD} 24^{\text {low }}$ cells. These results indicated that CD24 could not be used to isolate CSCs from lung adenocarcinoma cells.

The most important result of the present study is that CD24 expression is critically dependent on the smoking status of lung cancer patients. It was found that nicotine could inhibit CD24 expression in LLC cells by upregulation of RAS. Nicotine is believed to promote the tumorigenesis of lung cancer cells (15). An increase in Ras activity/expression is frequently found in numerous cancer types $(27,28)$. More and more evidence indicates that nicotine is able to activate Ras upon its interaction with nicotine acetylcholine receptors (15). In agreement with previous studies, the present study also confirmed that nicotine could induce RAS expression in LLC cells. In previous studies, the activation of RAS was able to downregulate CD24 expression at the mRNA and protein levels $(29,30)$. The present study also demonstrated that the expression of oncogenic Ras directly downregulated the expression of $\mathrm{CD} 24$ at the protein level. Furthermore, inhibition of RAS could partially restore CD24 expression in LLC cells. These results provided an integrated insight regarding the mechanism of nicotine-inhibited CD24 expression in LLC cells. Nicotine is well known to be an addictive component of cigarettes. Notably, no effects of smoking on CD24 expression were found in vivo. The main reason for this is that the level of nicotine may have been too low to influence established xenograft tumor models.

In summary, the principal findings of the present study were that: i) CD24 could be used as a prognostic marker in lung adenocarcinoma; ii) in vitro and in vivo experiments did not find a significant influence of CD24 on tumorgenicity of LLC cells; and iii) nicotine inhibited CD24 expression in LLC cells by upregulation of RAS. However, the downstream proteins of RAS should be analyzed in further studies.

\section{Acknowledgements}

Not applicable.

\section{Funding}

This study was supported by the National Natural Scientific Foundation of China (grant no. 81502558), the President Fund of Liaoning Medical University (grant no. XZJJ20140102) and the Biological Anthropology Innovation Team Project of Jinzhou Medical University (grant no. JYLJ201702).

\section{Availability of data and materials}

The analyzed datasets generated during the study are available from the corresponding author on reasonable request.

\section{Authors' contributions}

PX and FR were responsible for the study design, original article drafting and editing, data acquisition and data analysis. DHL, MA and BLB performed the experiments. DHL and PX were responsible for data analysis. DHL, MA and BLB were responsible for data acquisition. DHL, MA, BLB and PX were responsible for data interpretation and methodology. PX and FR were responsible for supervision of the whole study and funding acquisition. PX revised the manuscript. All authors have read and approved the final manuscript.

\section{Ethics approval and consent to participate}

The Ethical Committee of Jinzhou Medical University approved this investigation.

\section{Consent for publication}

Not applicable.

\section{Competing interests}

The authors declare that they have no competing interests. 


\section{References}

1. Chen W, Zheng R, Baade PD, Zhang S, Zeng H, Bray F, Jemal A, Yu XQ and He J: Cancer statistics in China, 2015. CA Cancer J Clin 66: 115-132, 2016.

2. Miller KD, Siegel RL, Lin CC, Mariotto AB, Kramer JL, Rowland JH, Stein KD, Alteri R and Jemal A: Cancer treatment and survivorship statistics, 2016. CA Cancer J Clin 66: 271-289, 2016.

3. Naylor EC, Desani JK and Chung PK: Targeted Therapy and Immunotherapy for Lung Cancer. Surg Oncol Clin N Am 25: 601-609, 2016

4. Zheng M: Classification and pathology of lung cancer. Surg Oncol Clin N Am 25: 447-468, 2016.

5. Mao Y, Yang D, He J and Krasna MJ: Epidemiology of Lung Cancer. Surg Oncol Clin N Am 25: 439-445, 2016.

6. Shan GP, Zhang P, Li P, Du FL and Yang YW: Numb gene enhances radiation sensitivity of nonsmall cell lung cancer stem sells. Cancer Biother Radiopharm 31: 180-188, 2016.

7. Gao C, Shen Y, Jin F, Miao Y and Qiu X: Cancer stem cells in small cell lung cancer cell line H446: Higher dependency on oxidative phosphorylation and mitochondrial substrate-level phosphorylation than non-stem cancer cells. PLoS One 11: e0154576, 2016.

8. Chang KJ, Yang MH, Zheng JC, Li B and Nie W: Arsenic trioxide inhibits cancer stem-like cells via down-regulation of Gli1 in lung cancer. Am J Transl Res 8: 1133-1143, 2016.

9. Fabregat I, Malfettone A and Soukupova J: New insights into the crossroads between EMT and stemness in the context of cancer. J Clin Med 5: E37, 2016.

10. Sheridan C, Kishimoto H, Fuchs RK, Mehrotra S, Bhat-Nakshatri P, Turner $\mathrm{CH}$, Goulet $\mathrm{R}$ Jr, Badve $\mathrm{S}$ and Nakshatri $\mathrm{H}$ : CD44 ${ }^{+} / \mathrm{CD} 24^{-}$breast cancer cells exhibit enhanced invasive properties: An early step necessary for metastasis. Breast Cancer Res 8: R59, 2006.

11. Jaggupilli A and Elkord E: Significance of CD44 and CD24 as cancer stem cell markers: An enduring ambiguity. Clin Dev Immunol 2012: 708036, 2012.

12. Liu H, Wang YJ, Bian L, Fang ZH, Zhang QY and Cheng JX: $\mathrm{CD} 44^{+} / \mathrm{CD} 24^{+}$cervical cancer cells resist radiotherapy and exhibit properties of cancer stem cells. Eur Rev Med Pharmacol Sci 20: 1745-1754, 2016.

13. Todoroki K, Ogasawara S, Akiba J, Nakayama M, Naito Y, Seki N, Kusukawa J and Yano H: CD44v3 ${ }^{+} / \mathrm{CD} 24^{-}$cells possess cancer stem cell-like properties in human oral squamous cell carcinoma. Int J Oncol 48: 99-109, 2016.

14. Salaria S, Means A, Revetta F, Idrees K, Liu E and Shi C: Expression of CD24, a stem cell marker, in pancreatic and small intestinal neuroendocrine tumors. Am J Clin Pathol 144: 642-648, 2015

15. Xu H, Mu J, Xiao J, Wu X, Li M, Liu T and Liu X: CD24 negative lung cancer cells, possessing partial cancer stem cell properties, cannot be considered as cancer stem cells. Am J Cancer Res 6 : 51-60, 2015.

16. Roudi R, Madjd Z, Ebrahimi M, Samani FS and Samadikuchaksaraei A: CD44 and CD24 cannot act as cancer stem cell markers in human lung adenocarcinoma cell line A549. Cell Mol Biol Lett 19: 23-36, 2014.
17. Karimi-Busheri F, Rasouli-Nia A, Zadorozhny V and Fakhrai H: $\mathrm{CD} 24^{+} / \mathrm{CD} 38^{-}$as new prognostic marker for non-small cell lung cancer. Multidiscip Respir Med 8: 65, 2013.

18. Majores M, Schindler A, Fuchs A, Stein J, Heukamp L, Altevogt P and Kristiansen G: Membranous CD24 expression as detected by the monoclonal antibody SWA11 is a prognostic marker in non-small cell lung cancer patients. BMC Clin Pathol 15: 19, 2015.

19. Xia P, Gou WF, Zhao S and Zheng HC: Crizotinib may be used in Lewis lung carcinoma: A novel use for crizotinib. Oncol Rep 30: 139-148, 2013.

20. Chu M, Guo J and Chen CY: Long-term exposure to nicotine, via ras pathway, induces cyclin D1 to stimulate G1 cell cycle transition. J Biol Chem 280: 6369-6379, 2005.

21. Alessandri G, Filippeschi S, Sinibaldi P, Mornet F, Passera P, Spreafico F, Cappa PM and Gullino PM: Influence of gangliosides on primary and metastatic neoplastic growth in human and murine cells. Cancer Res 47: 4243-4247, 1987.

22. Cavarra E, Bartalesi B, Lucattelli M, Fineschi S, Lunghi B, Gambelli F, Ortiz LA, Martorana PA and Lungarella G: Effects of cigarette smoke in mice with different levels of alpha(1)proteinase inhibitor and sensitivity to oxidants. Am J Respir Crit Care Med 164: 886-890, 2001.

23. Kristiansen G, Schlüns K, Yongwei Y, Denkert C, Dietel M and Petersen I: CD24 is an independent prognostic marker of survival in nonsmall cell lung cancer patients. Br J Cancer 88: 231-236, 2003.

24. Lee HJ, Choe G, Jheon S, Sung SW, Lee CT and Chung JH: CD24, a novel cancer biomarker, predicting disease-free survival of non-small cell lung carcinomas: A retrospective study of prognostic factor analysis from the viewpoint of forthcoming (seventh) new TNM classification. J Thorac Oncol 5: 649-657, 2010.

25. Ayre DC, Pallegar NK, Fairbridge NA, Canuti M, Lang AS and Christian SL: Analysis of the structure, evolution, and expression of CD24, an important regulator of cell fate. Gene 590: 324-337, 2016.

26. Hermann PC, Sancho P, Cañamero M, Martinelli P, Madriles F, Michl P, Gress T, de Pascual R, Gandia L, Guerra C, et al: Nicotine promotes initiation and progression of KRAS-induced pancreatic cancer via Gata6-dependent dedifferentiation of acinar cells in mice. Gastroenterology 147: 1119-33.e4, 2014.

27. Veluchamy JP, Spanholtz J, Tordoir M, Thijssen VL, Heideman DA, Verheul HM, de Gruijl TD and van der Vliet HJ: Combination of NK cells and cetuximab to enhance anti-tumor responses in RAS mutant metastatic colorectal cancer. PLoS One 11: $\mathrm{e} 0157830,2016$.

28. Hrustanovic G and Bivona TG: RAS-MAPK signaling influences the efficacy of ALK-targeting agents in lung cancer. Mol Cell Oncol 3: e1091061, 2015.

29. Pallegar NK, Ayre DC and Christian SL: Repression of CD24 surface protein expression by oncogenic Ras is relieved by inhibition of Raf but not MEK or PI3K. Front Cell Dev Biol 3: 47, 2015.

30. Morel AP, Lièvre M, Thomas C, Hinkal G, Ansieau S and Puisieux A: Generation of breast cancer stem cells through epithelial-mesenchymal transition. PLoS One 3: e2888, 2008. 